\title{
The Effect of Agility, Foot-Eye Coordination, and Balance on Dribbling Ability: An Ex Post Facto Research at Balai Baru Football Academy Padang
}

\begin{abstract}
Oktarifaldi $^{1 *}$, F Amra $^{1}$, V Soniawan ${ }^{1}$
${ }^{I}$ Sport Science Faculty, Universitas Negeri Padang, Jl. Prof Dr Hamka, Padang, Indonesia

*Corresponding author. Email: oktarifaldi69@yahoo.co.id

ABSTRACT

The lack of dribbling ability is the focus in this study since it becomes one of factors of the achievement at Balai Baru Football Academy (SSB Balai Baru) in Padang. This ability is influenced by several factors such as agility, foot-eye coordination and balance. This research aimed to reveal the effect of exogenous variables directly, causality, and simultaneously toward dribbling ability. This study employed quantitative research design with path analysis approach. Population of the research was 22 players or the total number of Balai Baru football academy players ranging from $9-12$ years old. The technique of sampling used was purposive sampling with the total number of sample were 19 players. The data then were obtained through the arrowhead agility test to measure agility; shoot-on-target to measure foot-eye coordination; bass test to measure balance; and the short dribbling test to measure dribbling ability. The results show that: (1) agility directly and significantly influenced toward dribbling ability; (2) foot-eye coordination directly and significantly influenced toward dribbling ability; (3) balance has direct and significant influence toward dribbling ability; (4) agility indirectly influences dribbling ability through balance; (5) foot-eye coordination indirectly influences dribbling ability through balance; (6) agility, foot-eye coordination and balance influence dribbling ability simultaneously. Based on the results, it is highly suggested to train agility, foot-eye coordination, and balance in order to improve dribbling ability of football players especially those who are in 9-12 years Old.
\end{abstract}

Keywords: Agility, foot-eye coordination, balance on dribbling ability, ex post facto

\section{INTRODUCTION}

Football is one of the popular sports and a potential profession in Indonesia. Nowadays, the trend shows great interests from people in educating their children in a football academy or soccer club regularly established by football association, private football academy, and so on in order to prepare them adequate skills and techniques. This research puts focus on one of football academies in Padang city named Balai Baru Football Academy (SSB Balai Baru). It was chosen because it has carried out coaching with training in improving dribbling ability. According to John (2007), "There are quite right, particularly at advanced-level play but dribbling is still the most important individual skill, and is the most fun for a child. The passing theory doesn't work well at the youngest age levels. It takes a long time before kids get the idea. Beginners don't move to open spaces to receive a pass; they often run up too close to their teammate to get a pass, and they don't return passes. A child must know how to dribble. Dribbling is also easier to learn. Passing skills, learning to spot an open teammate, and the ability to receive a pass come slowly. Good dribblers are the ones who will stand out in game. Go watch any game at the younger ages. Those who can dribble do quite well". In short, dribbling is one part of the techniques that must be mastered by every player to play football smoothly in order to achieve high achievements.

Dribbling is a technique that is quite dominant in football coaching, especially at a young age or an early level. As stated to John, the technique that is more dominant in football is dribbling. Dribbling in football can be categorized into dribble actions while accelerating and dribble actions with quick changes of direction. Acceleration is of great importance, as soccer players only cover short distances (mean distance 10$20 \mathrm{~m}$ ) at maximal effort) (Cometti, Maffiuletti, Pousson, Chatard, \& Maffulli, 2001; Reilly, Bangsbo, \& Franks, 2000a; Spinks, Murphy, Spinks, \&Lockie, 2007, in Barbara et al 2010). Given that dribbling speed is considered critical to the outcome of the whole game (Huijgen, Elferink-Gemser, Post\& Visscher, 2010 in Journal of Sport Science, 2015), it has been measured a number of times as element of soccer skill. Moreover, Luxbacher (2011) explains that dribbling a ball in football is similar with the one in basketball which is to 
defend the ball while running through the opponents and into open space.

Based on the observation and interview with the coach, there is lack of dribbling ability of Balai Baru Football Academy players. It can be seen on the field that when players were dribbling balls, they are not well-controlled, easily released and often seized by opponents. In the other words, the balls are not always mastered by the players. Many causes can be the reasons why this problem occurs. These can be from players' physical conditions such as agility, balance and coordination. Agility is a dominant physical element in dribbling. Scheunemann et.al (2012) state that physical trainings given to the players in the early ages (U9 U12) are to develop their agility, speed, coordination and balance. Agility has traditionally been defined as the ability to change direction rapidly and accurately (Alricsson et al. 2001; Baechle 1994; Barrow and McGee 1971; Tim and Jeremy 2013). Agility has more recently been defined as "a rapid whole-body movement with change of velocity or direction in response to a stimulus" (She pard dan Young 2006 in Waren, Brian dan Greg 2015). The players who have good agility will be easier to accomplish the movement tasks effectively in accordance with their goals and expectations.

In addition to agility, there is a pertinent component named balance. For the human body, balance is the ability to act on the body, gravitation of the body, and the sequence of under the influence of internal and external forces (Akman and Karatas 2003 in Inch, 2017). This element is highly needed in every sports movement, especially in football techniques. In football games, when doing dribbling movements, the dominant balance is dynamic balance which is the ability to maintain stability while forecasting and reacting to alteration as the body moves through the infinite (Gualtieri et.al 2008 in Inch, 2017). According to The President's Council on Physical Fitness and Sports(2000), dynamic balance is the component of skill related fitness that is how the body maintains balance boh in static or dynamic condition. Moreover, Mackenzie (2003:21) also explains "Balance or coordination have to be developed through many different methods. Exercises on the wobble board and balance beam are great for this. With a little imagination one can think of many things to challenge an athlete's balance and coordinating, balancing on a wobble board while juggling". From this statement, it can be concluded that good balanced will make players easier to realize football techniques such as dribbling.

Another important element in dribbling is coordination. As stated by Bafirman (2013), coordination is the ability to move parts of body in the same time. Schmidt (in Sukadiyanto, 2011) argues that "coordination is the movement combination of two or more joints in which each of them relates each other in order to result a movement skill. In his book, Schreiner (2000) argues that "Several muscles are needed to enable the body to perform football movements properly, quickly, powerfully and enduringly. The exact coordination of skeletal muscles and central nervous system is regulated and controlled by bodily processes that are covered by the term "coordination". According to Bompa (1994), actually there are two kinds of coordination namely general and specific coordination. The former is the ability of all of parts of body to adjust and manage moves simultaneously in a movement. Therefore, every movement involves parts of muscles, nervous systems, and joints. The latter is the coordination among body parts simultaneously. Furthermore, Schreiner (2000) explains that ... it relates to learning, controlling and using movements. Soccer players should be capable of learning new techniques quickly, economically and precisely, and adjusting them to take account of unexpected event. Players who have been taught good coordination can control their movements when they have to act quickly, under pressure from an opponent, in tight situation.

Based on the problem identified in the observation phase, the importance of dribbling for each player at Balai Baru Football Academy is highly needed. Therefore, it is necessary to conduct a research on dribbling skills of all players. The study was based on the assumption that the lack of dribbling ability was caused by internal factors namely players' agility, eyefoot coordination and balance. This study also aims to look at the relation and causality relationship between agility, eye-foot coordination and the balance of players to reveal the causes of the decline of achievement in football and to solve the problem.

\section{METHODOLOGY}

The method used in this study is a quantitative one using Path Analysis approach, which uses structural equations to reveal the causality of the dimensions of agility (X1), eye-foot coordination (X2), and balance (X3) on dribbling ability (Y). This research is conducted to find out whether there is a direct or indirect influence of the independent variables on the dependent variables by applying Path Analysis approach. The samples of this study were 19 players at Balai Baru Football Academy. The ability to dribble was tested by using the Test Course of The Short Dribbling Test instrument and dribbling agility was tested with Arrowhead Agility Test instrument provided by Bangsbo (2011), Eye-Foot Coordination was tested by using the Eye-Foot Coordination Test Target instrument from Winarno (2014) and the balance was tested using the Bass Test Track instrument from Widiastuti (2011). 


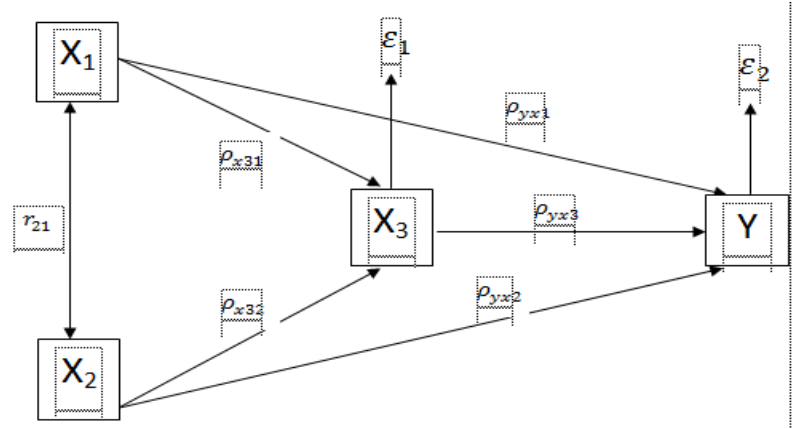

Figure 1. Research design by Engkos and Riduan (2012).

\section{RESULT AND DISCUSSION}

The data in this study were analyzed using a path analysis approach in which in the process there are two pathways. The Sig score and the Standardized Beta Coefficients of each path have to be calculated before testing the hypotheses.

The coefficient of first path

The coefficient of the first path is to figure out the impact of X1 and X2 toward X3 .

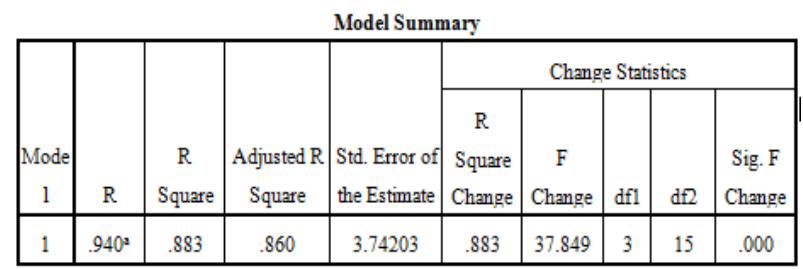

a. Predictors: (Constant), Balance (X3), Agility (X1), Foot-Eye coordination (X2)

\begin{tabular}{|c|c|c|c|c|c|c|}
\hline \multicolumn{2}{|c|}{ Model } & $\begin{array}{l}\text { Sum of } \\
\text { Squares }\end{array}$ & $D f$ & $\begin{array}{l}\text { Mean } \\
\text { Square }\end{array}$ & F & Sig. \\
\hline \multirow[t]{3}{*}{1} & $\begin{array}{l}\text { Regres } \\
\text { sion }\end{array}$ & 1589.991 & 3 & $\begin{array}{c}529.99 \\
7\end{array}$ & 37.849 & $.000^{\mathrm{a}}$ \\
\hline & $\begin{array}{l}\text { Residu } \\
\text { al }\end{array}$ & 210.042 & 15 & 14.003 & & \\
\hline & Total & 1800.033 & 18 & & & \\
\hline
\end{tabular}

a. Predictors: (Constant), Balance (X3), Agility (X1), Foot-Eye coordination (X2)

b. Dependent Variable: Dribbling $(Y)$

$$
\text { Coefficients }{ }^{\mathbf{a}}
$$

\begin{tabular}{|l|r|r|r|r|r|}
\hline \multirow{2}{*}{ Model } & \multicolumn{2}{|c|}{$\begin{array}{c}\text { Unstandardized } \\
\text { Coefficients }\end{array}$} & $\begin{array}{c}\text { Standardized } \\
\text { Coefficients }\end{array}$ & & \\
\cline { 2 - 5 } & \multicolumn{1}{|c|}{ B } & \multicolumn{1}{c|}{$\begin{array}{c}\text { Std. } \\
\text { Error }\end{array}$} & \multicolumn{1}{c|}{ Beta } & \multicolumn{1}{c|}{ T } & Sig. \\
\hline 1 (Constant) & -2.871 & 5.062 & & -.567 & .579 \\
Kelincahan (X1) & .498 & .127 & .498 & 3.912 & .001 \\
Koordinasi Mata- & .222 & .133 & .222 & 1.670 & .016 \\
Kaki (X2) & & & & & \\
Keseimbangan (X3) & .337 & .131 & .337 & 2.577 & .021 \\
\hline
\end{tabular}

a. Dependent Variable: Dribbling (Y)

The coefficient of second path

The coefficient of the first path is to figure out the impact of exogenous variables $(\mathrm{X} 1, \mathrm{X} 2$ dan $\mathrm{X} 3)$ toward endogenous ones (Y).
Model Summary

\begin{tabular}{|c|c|c|c|c|c|c|c|c|c|}
\hline \multirow[b]{2}{*}{$\begin{array}{l}\text { Mo } \\
\text { del }\end{array}$} & \multirow[b]{2}{*}{$\mathrm{R}$} & \multirow[b]{2}{*}{$\begin{array}{c}\mathrm{R} \\
\text { Square }\end{array}$} & \multirow{2}{*}{$\begin{array}{c}\text { Adjuste } \\
\mathrm{dR} \\
\text { Square }\end{array}$} & \multirow{2}{*}{$\begin{array}{l}\text { Std. Error } \\
\text { of the } \\
\text { Estimate }\end{array}$} & \multicolumn{5}{|c|}{ Change Statistics } \\
\hline & & & & & $\begin{array}{c}\text { R Square } \\
\text { Change }\end{array}$ & $\begin{array}{c}\mathrm{F} \\
\text { Change }\end{array}$ & $\mathrm{df1}$ & df2 & $\begin{array}{l}\text { Sig. F } \\
\text { Change }\end{array}$ \\
\hline & $.739^{\mathrm{a}}$ & .546 & .489 & 7.14756 & .546 & 9.621 & 2 & 16 & .002 \\
\hline
\end{tabular}

a. Predictors: (Constant), Foot-Eye coordination(X2), Agility (X1)

ANOVA $^{\text {b }}$

\begin{tabular}{|l|r|r|r|r|r|}
\hline Model & \multicolumn{1}{|c|}{$\begin{array}{c}\text { Sum of } \\
\text { Squares }\end{array}$} & df & $\begin{array}{c}\text { Mean } \\
\text { Square }\end{array}$ & F & Sig. \\
\hline Regression & 983.003 & 2 & 491.502 & 9.621 & $.002^{\mathrm{a}}$ \\
Residual & 817.402 & 16 & 51.088 & & \\
Total & 1800.405 & 18 & & & \\
\hline
\end{tabular}

a. Predictors: (Constant), Foot-Eye coordination (X2), Agility (X1)

b. Dependent Variable: Balance (X3)

Coefficients

\begin{tabular}{|c|c|c|c|c|c|}
\hline \multirow[b]{2}{*}{ Model } & \multicolumn{2}{|c|}{$\begin{array}{l}\text { Unstandardized } \\
\text { Coefficients }\end{array}$} & \multirow{2}{*}{$\begin{array}{c}\begin{array}{c}\text { Standardized } \\
\text { Coefficients }\end{array} \\
\text { Beta }\end{array}$} & \multirow[b]{2}{*}{$\mathrm{T}$} & \multirow[b]{2}{*}{ Sig. } \\
\hline & $B$ & Std. Error & & & \\
\hline (Constant) & 9.627 & 9.365 & & 1.028 & .319 \\
\hline Agility $(X 1)$ & .350 & .227 & .350 & 1.544 & .142 \\
\hline $\begin{array}{l}\text { Foot-Eye coordination } \\
(\mathrm{X} 2)\end{array}$ & .457 & .227 & .457 & 2.016 & .061 \\
\hline
\end{tabular}

a. Dependent Variable: Balance (X3)

The direct impact of agility toward dribbling ability

The individual test of $\mathrm{X} 1$ toward $\mathrm{Y}$ found that the result of path coefficient is $\rho Y X 1=0.498$. Based on the result of calculation carried out using the SPSS program17, the value of sig $=0.001$ is smaller than the probability value $\alpha=0.05$ or in the other way the value of $0.001<0.05$ means $\mathrm{Ha}$ is accepted and $\mathrm{H} 0$ is rejected. Characteristics of the agility are changes in direction of running, changes in body position, and changes in direction of body parts in performing techniques in football especially in dribbling the ball. Therefore, agility directly influences dribbling performed by football players at Balai Baru Football Academy.

The direct impact of Eye-Foot Coordination on dribbling ability

The individual test of $\mathrm{X} 2$ toward $\mathrm{Y}$ was conducted found that the results of path coefficient value is $\rho Y X 2$ $=0.222$ Based on the result of calculation carried out using the SPSS program17, it was obtained a value of $\operatorname{sig}=0.016$ smaller than the probability value $\alpha=0.05$, the value of $0.016<0.05$ meansHO is rejected and $\mathrm{Ha}$ is accepted. When comparing with other variables, foot- 
eye coordination is a dominant element of physical condition, but the influence given directly to dribbling ability is the smallest among other variables. Based on the theoretical review stated before, the theoretical framework in this study can be accepted empirically that coordination truly has a relationship and impact on dribbling abilities. So, foot-eye coordination directly influences dribbling performed by football players at the Balai Baru Football Academy

The direct Impact of balance on dribbling ability

The individual test of $\mathrm{X} 3$ toward $\mathrm{Y}$ was conducted found that the results of path coefficient value is $\rho Y X 3$ $=0.337$. Based on the result of calculation carried out using SPSS program 17, it was obtained sig value = 0.021 that is smaller than the probability value $\alpha=0.05$. The value $0.021<0.05$ means that $\mathrm{Ha}$ is accepted and $\mathrm{HO}$ is rejected or it can be stated that the coefficient of path analysis is significant. As explained in the theoretical review, balance can be defined as the ability of a person to complete the task of movement starting from stimulation to the realization of the movement in a controlled manner. Moreover, it is also the ability to maintain the position of the body both in static conditions (small motion space) and dynamic or the ability to move from a place to another one. Being capable to control body means to control the muscular organs of the muscles in carrying out a movement, especially dribbling movement. Thus, from the theories and findings, it can be interpreted that balance is a physical element that is always needed and must be owned by every football player. So, the balance has a direct effect on dribbling ability

\section{Indirect effect of agility on dribbling through players' balance}

The analysis of the agility toward dribbling through balance of Bala Baru Football Academy players showed the impact of agility on dribbling through balance is 0.652 or $42.50 \%$. This finding can be assumed that players who have good ability to dribble the ball certainly have good agility and balance as well. Experts explain that for children (basic) levels, the dominant player in a match or a football game is the one who has good dribbling ability.

Indirect effect of foot-eye coordination on dribbling through players' balance

The analysis of the foot-eye coordination toward dribbling through balance of Balai Baru Football Academy players showed the impact of foot-eye coordination on dribbling through balance is 0.339 or $11.49 \%$. Foot-eye coordination is a variable that has strong and mutual relationship with balance toward dribbling. However, the effect resulted by foot-eye coordination directly is different with Balance. Based on the finding, the maximum result will be obtained if foot-eye coordination is integrated with balance. The result of this study indicates that foot-eye coordination has strong relationship and smaller impact than other research variables on dribbling ability

The effect of agility, foot-eye coordination and balance toward player's dribbling ability at Balai Baru Football Academy

The result of the analysis of the data reveals that Rsquare is 0.883 and from Annova table obtained $\mathrm{F}=$ 37.84 with probability $(\mathrm{sig})=0,000$ so that the value of sig is smaller than $\alpha=0.05$ and it means that $\mathrm{H} 0$ is rejected and Hais accepted. So, agility, foot-eye coordination and balance simultaneously influence dribbling ability of the players. The analysis of the agility, foot-eye coordination and balance towards dribbling (X1, $\mathrm{X} 2$ and $\mathrm{X} 3$ to $\mathrm{Y}$ ) variables is $88.3 \%$ and the remaining $11.7 \%$ is influenced by other factors. The result of this study shows that each exogenous variable namely agility, foot-eye coordination, and balance simultaneously give impact on endogenous variables that is dribbling ability and this assumption also can be accepted empirically. Thus, the findings of this study figure out that exogenous variables simultaneously have a significant effect on endogenous variables

\section{CONCLUSION}

Based on the result of the study, there are several conclusions as follow: 1) There is a direct and significant impact of agility on dribbling ability of football players at Balai Baru Football Academy. The percentage is $24,80 \%$; 2) There is a direct and significant impact of foot-eye coordination on dribbling ability. The percentage is $4,92 \%$; 3 ) There is a direct and significant effect of foot-eye coordination toward dribbling ability(dribbling) of football players at the Balai Baru Football Academy. The percentage is $11,35 \%$; 4) There is an indirect impact of agility toward dribbling ability of football players at the Balai Baru Football Academy. The percentage is $42,50 \%$; 5) There is an indirect impact of foot-eye coordination toward dribbling ability of football players at the Bala Baru Football Academy. The percentage is $11,49 \%$; 6) There is a significant impact of agility, foot-eye coordination, and balance toward dribbling ability of football players at the Balai Baru Football Academy. The percentage is $88,30 \%$

\section{REFERENCES}

[1] John, P. M (2007). Coaching youth soccer. Cincinnati, Ohio : Batterway Book,

[2] Barbara c. H. Huijgen, Marije T. ElferinkGemser, Wendy Post \& Chris Visscher. 2010,

[3] Development of dribbling in talented youth soccer players aged 12-19 years: A longitudinal study. 
Journal of Sports Sciences May 2010; 28(7): 689698. Acces on Juli 282016

[4] Journal Of Sport and Science. 2015. Dribbling determinants in sub-elite youth soccer players. http://mc.manuscriptcentral.com/rjsp

[5] B Joseph. A Luxbacher. (2011). Sepak Bola. Jakarta: PT RAJA GRAFINDO PERSADA.

[6] Timo. S Scheunemann,dkk. (2012). Kurikulum dan pedoman dasar sepak bola Indonesia. (untuk usia dini (U5 - U12) usia muda (U13 - U20) \& Senior. Jakarta: PSSI.

[7] Tim J. Gabbett and Jeremy M. Sheppard. 2013. Testing and Training Agility (In book: Physiological testing of elite athletes, Edition: 2nd edition., Chapter: Speed and Agility, Publisher: Human Kinetics).Australian Institute of Sport.

[8] Warren B. Young, Brian Dawson dan Greg J. Henry. (2015).International Journal of Sports Science \& Coaching Volume 10 Number 12015.

[9] Bafirman, (2013). Fisiologi olahraga. Padang : Wineka Media.

[10] Sukadiyanto, (2011). Pengantar teori dan metodologi melatih fisik. Bandung : Lubuk Agung.

[11] Schreiner, Peter (2000). Coordination, agility, and speed training for soccer. Reedswain Publishing. Spring City : Peninsylvania Germany.

[12] Bompa, Tudor O, (1994). Power training for sport: Plyometrics explosive power development (cetakan kedua). Canada: Mosaic Press.

[13] Inci Kesilmis. 2017. The Comparison of the Different Balance Performance of Soccer Players Versus Sedentary. International Journal of Sports Science and Physical Education.

[14] The President's Council on Physical Fitness and Sports. (2000).

[15] Brian Mackenzie (2003) The world sports science training workbook. London : Electric Word plc.

[16] Bongsbo Jens end Mohr Magni. (2011) Fitness Training in Soccer. Nagoya, Japa,

[17] Winarno, (2014). Evaluasi hasil belajar pendidikan jasmani olahraga dan kesehatan. Penerbit: Laboratorium Jurusan Ilmu Keolahragaan. Malang: Universitas Negeri Malang.

[18] Widiastuti. (2011). Tes dan pengukuran olahraga. Jakarta: PT. BUMI TIMUR JAYA.

[19] Riduan dan Kuncoro. E (2012). Cara menggunakan dan memakai path analisis. Bandung : ALVABETA. 